\title{
OPEN Distribution and safety assessment of heavy metals in fresh meat from Zhejiang, China
}

\author{
Jian Long Han, Xiao Dong $\operatorname{Pan}^{\bowtie}$ \& Qing Chen
}

There are increasing concerns on heavy metals in animal derived foods. We analyzed the levels of As, $\mathrm{Cd}, \mathrm{Cr}, \mathrm{Cu}, \mathrm{Hg}, \mathrm{Ni}$, and $\mathrm{Pb}$ in 1066 fresh meat samples including pork, beef, mutton, chicken and duck from Zhejiang province, southeast $\mathrm{China}$. The average levels of $\mathrm{As}, \mathrm{Cd}, \mathrm{Cr}, \mathrm{Cu}, \mathrm{Hg}, \mathrm{Ni}$, and $\mathrm{Pb}$ were $0.018,0.002,0.061,0.801,0.0038,0.055$, and $0.029 \mathrm{mg} / \mathrm{kg}$ wet weight respectively. There are significant positive correlations among $\mathrm{Cd}, \mathrm{Hg}$ and $\mathrm{Pb}(P<0.05)$ and negative correlations for $\mathrm{Cu}-\mathrm{Pb}$ or Cu-Cd $(P<0.05)$. The exposure assessment showed that the health risk to humans by consuming these meat products was relatively low. However, regular monitoring of heavy metals in meat products is still recommended considering their intensive industrial activities.

Meat products are major sources of human nutrients, including protein, minerals, vitamins, and fats. Based on Statistical Yearbook of China 2016, Chinese output of pork, beef and mutton reached 86.25 million tones ${ }^{1}$. It has become the main pork producer, accounting for about $50 \%$ of the world's production ${ }^{2}$. Although most of Chinese residents have a plant-food-based dietary protein pattern, there is a rapid growth of meat consumption ${ }^{3}$. Recently, concerns have been raised about various toxic elements in meat products.

The contamination of harmful elements in livestock and poultry are caused by animal feeds, especially in some areas with intense manufacturing activities, industrial emissions, coal combustion, and ore mining ${ }^{4,5}$. When toxic elements, such as cadmium $(\mathrm{Cd})$ and lead $(\mathrm{Pb})$ are released into water, soil or air, they could be accumulated by plants and fishes, which are the main raw materials of animal feeds ${ }^{6-8}$. For example, Tao et al. ${ }^{9}$ reported that the incidence rates of cadmium $(\mathrm{Cd})$, mecury $(\mathrm{Hg})$, chromium $(\mathrm{Cr})$, and arsenic (As) contamination for feedstuffs and feeds were high. Furthermore, animal feeds were commonly contaminated with Cr, followed by As, Cd, and $\mathrm{Hg}$. Wang et al. ${ }^{10}$ observed high level of $\mathrm{Cr}$ in meat products, which possibly originated from the dietary feeds of animal husbandry.

The high exposure to these metals in meat consumption has negative effects to human body, such as nerve damage, nephropathy and cancers ${ }^{11-13}$. For example, $\mathrm{Pb}$ can lead to kidney failure, cardiovascular disease and abnormal nervous development of children ${ }^{14}$. Chronic exposure of $\mathrm{Cd}$ can cause liver harm, bone degeneration, blood damage, and renal dysfunction ${ }^{15}$. Hg could damage the nervous system of unborn and newborn children ${ }^{16}$. Therefore, it is necessary to monitor and control toxic elements in meat product from China, one of the largest meat production and consumption countries ${ }^{17,18}$.

Zhejiang province with a high population density is the fast-developing area in the southeast of China. Our previous studies have reported the possible pollution of heavy metals in vegetables, rice, marine fish and seaweeds in Zhejiang,11,19-21. However, to our knowledge, few studies on metal contamination in meat products were reported. The aim of this study was to investigate distribution of heavy metals in livestock and poultry meat and evaluate the health risk to local inhabitants. Our data may provide some insights into toxic elements accumulation in farmed animals and serve as a basis for profiling the public health problem.

\section{Materials and methods}

Sampling. Total 1066 meat samples were collected in Zhejiang, China whose latitudes range from $27^{\circ} 09^{\prime}$ to $31^{\circ} 11^{\prime} \mathrm{N}$, and the longitudes from $118^{\circ} 02^{\prime}$ to $122^{\circ} 57^{\prime} \mathrm{E}$. Fresh edible meats of livestock and poultry were collected in 11 sampling areas as shown in Fig. 1 which was drawn by software of MapGIS K9 SP2 free trial edition (Zondy Cyber Comp., China, http://www.mapgis.com/index.php/index-view-aid-280.html). The detailed edible parts such as leg, chest and waist were randomly selected. The samples were pork (511), beef (184), mutton (47), chicken (250) and duck (74) collected from 2018 to 2020. All samples transported in plastic bags were refrigerated at $-20^{\circ} \mathrm{C}$ until later analysis in the laboratory. The storage period was not more than 7 days. 


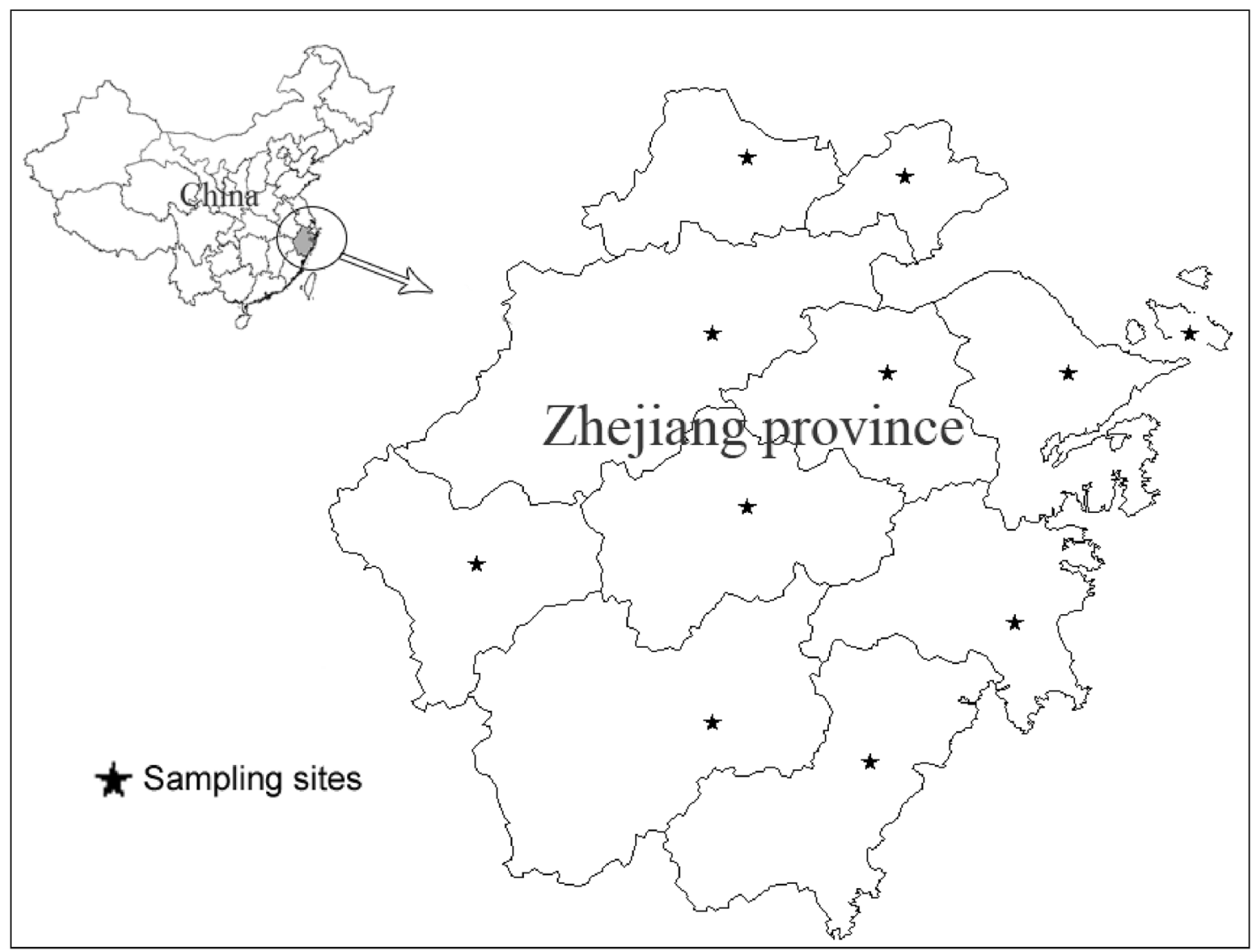

Figure 1. The simple map of sampling areas in Zhejiang province of China.

\begin{tabular}{|l|l|l|l|l|}
\hline \multirow{3}{*}{} & \multicolumn{2}{|l|}{ GBW10018 Chicken } & \multicolumn{2}{l|}{ GBW10051 pork liver } \\
\cline { 2 - 5 } & Certified $(\mathbf{m g} / \mathbf{k g})$ & Measured $(\mathbf{m g} / \mathbf{k g})$ & Certified $(\mathbf{m g} / \mathbf{k g})$ & Measured $(\mathbf{m g} / \mathbf{k g})$ \\
\hline $\mathrm{As}$ & $0.109 \pm 0.013$ & $0.099 \pm 0.021$ & $1.4 \pm 0.3$ & $1.5 \pm 0.2$ \\
\hline $\mathrm{Cd}$ & - & - & $1.00 \pm 0.07$ & $0.98 \pm 0.06$ \\
\hline $\mathrm{Hg}$ & $0.0036 \pm 0.0015$ & $0.0039 \pm 0.0018$ & $0.045 \pm 0.008$ & $0.049 \pm 0.011$ \\
\hline $\mathrm{Pb}$ & $0.11 \pm 0.02$ & $0.10 \pm 0.04$ & $0.12 \pm 0.03$ & $0.11 \pm 0.06$ \\
\hline $\mathrm{Cu}$ & $1.46 \pm 0.12$ & $1.36 \pm 0.22$ & $52 \pm 3$ & $50 \pm 6$ \\
\hline $\mathrm{Cr}$ & $0.59 \pm 0.11$ & $0.55 \pm 0.17$ & $0.23 \pm 0.06$ & $0.19 \pm 0.09$ \\
\hline $\mathrm{Ni}$ & $0.15 \pm 0.03$ & $0.11 \pm 0.08$ & - & - \\
\hline
\end{tabular}

Table 1. Determination of certified reference materials $(n=6)$.

Chemical analysis. The concentrations of arsenic (As), cadmium (Cd), chromium (Cr), copper (Cu), mecury $(\mathrm{Hg})$, nickel $(\mathrm{Ni})$, and lead $(\mathrm{Pb})$ were tested according to the Chinese standard analysis method of GB $5009.268-2016^{22}$. Briefly, samples $(0.5-1.0 \mathrm{~g})$ were digested in acid-clean Teflon vessels containing $6 \mathrm{~mL} \mathrm{HNO}_{3}$ in a Mars- 6 microwave digestion system (CEM, Charlotte, NC, USA). The samples in closed vessels were heated at $190{ }^{\circ} \mathrm{C}$ for $20 \mathrm{~min}$. After digestion, the residue was heated at $150^{\circ} \mathrm{C}$ till nearly dry. For the $\mathrm{Hg}$ test, the digested sample was directly diluted without heating for removing residual acid. Then, it was diluted to $20 \mathrm{~mL}$ by deionized water for instrumental analysis. $\mathrm{As}, \mathrm{Cd}, \mathrm{Cr}, \mathrm{Cu}, \mathrm{Hg}, \mathrm{Ni}$, and $\mathrm{Pb}$ in all samples were tested using inductively coupled plasma mass spectrometry (ICP-MS) (NexION 300, Perkin Elmer, Inc., Shelton, CT USA). For quality assurance and quality control purposes, sample blanks, certified reference materials (CRMs), and duplicates of the samples ( $10 \%$ of the load) were applied in each batch of treated samples.

Method validation. The analytical procedures were verified by analysis of appropriate certified reference materials (CRMs) using the same digestion and analytical methods. Two CRMs (Table 1) were purchased from National Research Center for Certified Reference Materials, China (NRCCRM). Quantitative results (no more than $10 \%$ of the certified value) were obtained for targeted elements of CRMs. Limits of detection (LODs) were 


\begin{tabular}{|l|l|l|l|l|l|l|l|}
\hline Element & $\boldsymbol{n}$ & Mean $^{\mathbf{a}}$ & P97.5 $^{\mathbf{a}}$ & Range & MAC $^{\mathbf{b}}$ & No. of $>$ MAC & LOD \\
\hline $\mathrm{As}$ & 1066 & 0.018 & 0.11 & 3.2 & 0.5 & 1 & 0.003 \\
\hline $\mathrm{Cd}$ & 1063 & 0.002 & 0.013 & 0.089 & 0.1 & 0 & 0.001 \\
\hline $\mathrm{Cr}$ & 1066 & 0.061 & 0.318 & 0.996 & 1 & 0 & 0.005 \\
\hline $\mathrm{Cu}$ & 1062 & 0.801 & 4.09 & 9.81 & - & - & 0.005 \\
\hline $\mathrm{Hg}$ & 1066 & 0.0038 & 0.0252 & 0.076 & 0.05 & 2 & -0003 \\
\hline $\mathrm{Ni}$ & 1066 & 0.055 & 0.42 & 1.4 & - & - & 0.004 \\
\hline $\mathrm{Pb}$ & 1060 & 0.029 & 0.18 & 0.536 & 0.2 & 10 & 0.004 \\
\hline
\end{tabular}

Table 2. The concentration of heavy metals in meat samples from Zhejiang province ( $\mathrm{mg} / \mathrm{kg}$ fresh weight). aTarget analytes with concentrations lower than LOD were treated as one-half of LOD when calculating the mean values. ${ }^{\mathrm{b}}$ Maximum allowable concentrations of contaminants in foods.

defined as 3 times the standard deviation of 10 runs of blank measurements. LODs of As, $\mathrm{Cd}, \mathrm{Cr}, \mathrm{Cu}, \mathrm{Hg}, \mathrm{Ni}$, and $\mathrm{Pb}$ were $0.003,0.001,0.005,0.005,0.0003,0.004$ and $0.004 \mathrm{mg} / \mathrm{kg}$, respectively.

Consumption data. The meat consumption data were provided by the Zhejiang Food and Drug Administration of China ${ }^{23}$. Briefly, it performed the food consumption survey in 2008. In this survey, 9798 people represented certain areas were questioned twice about their last 24 -h consumption. Furthermore, the selection of interviewed people and the moment of the interview were designed for a representative consumption profile of the population over 1 year.

Health risk assessment. According to the recommendation of the report Reliable Evaluation of LowLevel Contaminations of Food issued by WHO, half of LOD was assigned to all results of element levels below the LOD, where the proportion of data below the LOD is not more than $60 \%{ }^{24}$.

The targeted hazard quotient (THQ) and hazard index (HI) were used to estimate health risk according to US EPA's IRIS database ${ }^{25}$. We adopted the mean and 97.5th percentile (P97.5) of obtained element level to represent the consumers with normal and high exposure, respectively ${ }^{21}$. The sum of all THQs for each element was referred as the HI. The formulas were as follows:

$$
\begin{gathered}
\text { Exposure Dose }=\frac{C i \times D i \times E d}{B w \times A t} \\
\text { Tageted Hazard Quotient (THQ) }=\frac{\text { Exposure Dose }}{R f D} \\
\text { Hazard Index }(\mathrm{HI})=\sum_{k=1}^{n=k} \text { Targeted Hazard Quotient }
\end{gathered}
$$

$\mathrm{Ci}$ is the average or P97.5 concentration of the element in meat samples ( $\mathrm{mg} / \mathrm{kg}$ wet weight); $\mathrm{Di}$ is the daily intake of livestock and poultry meat $(112.9 \mathrm{~g} / \text { capita/day })^{23}$; Ed is the average exposure duration (e.g., 70 years $)^{20}$; Bw is the average weight (e.g., $60 \mathrm{~kg})^{20}$; At is the average lifetime (e.g., 70 years) ${ }^{11}$. RfD is the recommended reference dose (RfD ${ }^{26}$; According to US EPA guidelines for assessing conservative risk, HI were calculated by sum of the THQ. When $\mathrm{HI}<1$, no health risk is expected to occur; If $\mathrm{HI} \geq 1$, there is moderate or high risk for adverse human effects.

Statistical analysis. Data analysis and statistical analysis were performed using Excel (2017 edition) and SPSS16 (Tried edition). The difference was considered as significant by single factor analysis (one-way ANOVA) when $P<0.05$. The correlation between each factor was analyzed by Pearson correlation analysis.

\section{Results and discussion}

Heavy metals in meats. Total 1066 meat samples including 511 pork samples, 250 chicken, 184 beef, 74 duck, and 47 mutton purchased from local markets of Zhejiang were analyzed in this study. As shown in Tables 2 and 3, average levels of $\mathrm{As}, \mathrm{Cd}, \mathrm{Cr}, \mathrm{Cu}, \mathrm{Hg}, \mathrm{Ni}$, and $\mathrm{Pb}$ were $0.018,0.002,0.061,0.801,0.0038,0.055$, and $0.029 \mathrm{mg} / \mathrm{kg}$ wet weight respectively. Based on the Chinese National Food Safety standard ${ }^{27}$, the maximum allowable concentrations (MAC) of $\mathrm{As}, \mathrm{Cd}, \mathrm{Cr}, \mathrm{Hg}$ and $\mathrm{Pb}$ in meat in China were $0.5,0.1,1,0.05 \mathrm{and} 0.2 \mathrm{mg} / \mathrm{kg}$. The number of sample exceeding the MAC is 1 for As, 2 for $\mathrm{Hg}$ and 10 for $\mathrm{Pb}$. Our results were similar with those found in Beijing China, where there were $\mathrm{Cr}(0.573 \mathrm{mg} / \mathrm{kg}), \mathrm{Cd}(0.015 \mathrm{mg} / \mathrm{kg}), \mathrm{Pb}(0.167 \mathrm{mg} / \mathrm{kg}), \mathrm{As}(0.053 \mathrm{mg} /$ $\mathrm{kg}), \mathrm{Hg}(0.018 \mathrm{mg} / \mathrm{kg})$ in meats (pork, beef, mutton, chicken $)^{28}$ and the results from Taiwan, China ${ }^{29}$. In some potential polluted areas, average levels of heavy metals, such $\mathrm{Cd}$ and $\mathrm{Pb}$ were more than $0.2 \mathrm{mg} / \mathrm{kg}$ in meat product $^{30,31}$. It shows that levels of these metals in animals change with different area, where may have diverse sources of the contaminant. 


\begin{tabular}{|c|c|c|c|c|}
\hline Meat type & Area & $\mathbf{N}$ & Mean level (mg/kg fresh weight) & References \\
\hline \multirow{3}{*}{ Pork, } & Italy (meat products) & 100 & $\begin{array}{l}\mathrm{Cr} 0.15-0.23 ; \mathrm{Cd} 0.01-0.03 ; \mathrm{Hg} 0.01-0.02 ; \mathrm{Cu} 1.08-1.21 ; \mathrm{Pb} \\
0.22-0.38\end{array}$ & Barone et al. ${ }^{30}$ \\
\hline & Beijing, China & - & Cr 0.483; Cd 0.003; Pb 0.029; As 0.043; Hg 0.015 & Liang et al. ${ }^{28}$ \\
\hline & Zhejiang, China & 511 & $\begin{array}{l}\text { Cr 0.062; Cd 0.002; Pb 0.058; As 0.020; Hg 0.004; Cu 0.633; } \\
\text { Ni 0.058 }\end{array}$ & This study \\
\hline \multirow{3}{*}{ Beef } & Beijing, China & - & Cr 0.504; Cd 0.015; Pb 0.201; As 0.077; Hg 0.010 & Liang et al. ${ }^{28}$ \\
\hline & Iran & 72 & Cd 0.028; Cd 0.028; Hg 0.003 & Hashemi $^{33}$ \\
\hline & Zhejiang, China & 184 & $\begin{array}{l}\text { Cr 0.062; Cd 0.002; Pb 0.061; As 0.018; Hg 0.004; Cu 0.673; } \\
\text { Ni 0.061 }\end{array}$ & This study \\
\hline \multirow[b]{2}{*}{ Mutton } & Beijing, China & - & Cr 0.654; Cd 0.031; Pb 0.128; As 0.008; Hg 0.005 & Liang et al., $2019^{28}$ \\
\hline & Zhejiang, China & 47 & $\begin{array}{l}\text { Cr 0.045; Cd 0.002; Pb 0.061; As 0.008; Hg 0.003; Cu 0.956; } \\
\text { Ni 0.061 }\end{array}$ & This study \\
\hline \multirow{4}{*}{ Chicken } & Beijing, China & - & Cr 0.650; Cd 0.031; Pb 0.291; As 0.045; Hg 0.017 & Liang et al. ${ }^{28}$ \\
\hline & Guangzhou, China (Drumstick) & 30 & Cr 0.11; Cd 0.002; Pb 0.073; As 0.029; Cu 0.757; Ni 0.069 & Hu et al. ${ }^{32}$ \\
\hline & Pakistan & 60 & $\mathrm{Cd} 0.017 ; \mathrm{Pb} 0.16 ; \mathrm{Ni} 0.39$ & Abbas et al. ${ }^{29}$ \\
\hline & Zhejiang, China & 250 & $\begin{array}{l}\text { Cr 0.060; Cd 0.003; Pb 0.058; As 0.018; Hg 0.004; Cu 0.535; } \\
\text { Ni } 0.042\end{array}$ & This study \\
\hline \multirow[b]{2}{*}{ Duck } & Thailand & 90 & $\mathrm{~Pb} 3.13$ (dry wet); Cd 0.33 (dry wet); Cu 15.28 (dry wet) & Aendo et al. ${ }^{31}$ \\
\hline & Zhejiang, China & 74 & $\begin{array}{l}\text { Cr 0.073; Cd 0.003; Pb 0.058; As 0.014; Hg 0.004; Cu 3.1; Ni } \\
0.047\end{array}$ & This study \\
\hline
\end{tabular}

Table 3. Comparison of different metals in meat with some previous reports.

Different animal species may have different bio-accumulation ability to heavy metals. The average levels of $\mathrm{As}, \mathrm{Cd}, \mathrm{Cr}, \mathrm{Cu}, \mathrm{Hg}, \mathrm{Ni}$, and $\mathrm{Pb}$ in different meat samples were shown in Fig. 2. By comparison with beef, chicken, duck and pork, mutton had relative lower levels of As, $\mathrm{Cd}$, and $\mathrm{Cr}(P<0.05)$. Mutton accumulated lower levels of As, Cd, and $\mathrm{Cr}$, which may be caused by the grassy feed and less mineral supplement. High Cu concentration (average $3.1 \mathrm{mg} / \mathrm{kg}$ ) was found in duck meat. Considering the nearly $80 \%$ water content in duck meat, our result was similar with the report of Aendo et al. ${ }^{32}$, who found duck meat with $15.28 \mathrm{mg} / \mathrm{kg}$ dry weight for Cu in Thailand. For $\mathrm{Hg}, \mathrm{Ni}$, and $\mathrm{Pb}$, there was no significant difference among five targeted meats $(P<0.05)$. Furthermore, 4 of 248 chicken muscle samples contained $\mathrm{Pb}$ with levels above the safety threshold of $0.2 \mathrm{mg} / \mathrm{kg}$ (fresh weight $)^{27}$. The ratio of over-limit was lower than that reported in Guangzhou, China where 2 of 63 muscle samples had $\mathrm{Pb}$ contents exceeding this limit ${ }^{33}$. But, the mean level $(0.058 \mathrm{mg} / \mathrm{kg})$ was higher than reported in Korea $(0.005 \mathrm{mg} /$ $\mathrm{kg})^{34}$. The Cd $(0.002 \mathrm{mg} / \mathrm{kg})$ in beef was lower than report of Hashemi ${ }^{35}$ who found $0.28 \mathrm{mg} / \mathrm{kg} \mathrm{Cd}$ in Iran. Feeds and mineral supplement products may be one of many sources of heavy metal for these animals.

Pearson correlation analysis (Table 4 ) showed that there were significant positive correlations for $\mathrm{Cd}-\mathrm{Hg}$ $(r=0.9141, P<0.05), \mathrm{Pb}-\mathrm{Hg}(r=0.98837, P<0.05)$ and $\mathrm{Cd}-\mathrm{Pb}(r=0.9504, P<0.05)$ in meat samples. Negative correlations in $\mathrm{Cu}-\mathrm{Cd}(r=-0.6515, P<0.05)$ and $\mathrm{Cu}-\mathrm{Pb}(r=-0.6101, P<0.05)$ were found in our results. We suppose that two groups of $\mathrm{Cd}-\mathrm{Hg}-\mathrm{Pb}$ and $\mathrm{Cu}$ were accumulated by different sources. Actually, most of livestock and poultry in Zhejiang were farming with artificial feeds which may be the main source of heavy metals. The contamination incidence rates of harmful elements, such as $\mathrm{Cd}, \mathrm{Hg}, \mathrm{Pb}$, and $\mathrm{As}$ in feedstuffs and feeds were high, and the feeds were usually contaminated with contaminated with $\mathrm{Cr}$, followed by As, $\mathrm{Cd}$, and $\mathrm{Hg}^{9}$. The mean As contents of chicken feeds collected in Jiangsu province of southern China was reported to be $0.13 \mathrm{mg} / \mathrm{kg}^{36}$ while the total contents of As in poultry feeds in northeastern China varied from 0.02 to $6.42 \mathrm{mg} / \mathrm{kg}^{37}$. Studies found that level of $\mathrm{Cu}$ was 2 to 8 times higher than the required ones in poultry and livestock feeds in China ${ }^{36,37}$. As we known, compounds including $\mathrm{Cu}$ element were commonly used as a growth promoter in diets of poultry, especial duck ${ }^{38}$.

Exposure assessment and health risk. According to the data of food consumption survey ${ }^{23}$, the estimated livestock and poultry meat intake was $112.9 \mathrm{~g} / \mathrm{day} /$ person. The recommended reference doses (RfDs) or safe values were based on previous reports ${ }^{31,33}$. The mean and high exposure was presented by the average and P97.5 elements levels, respectively. As shown in Table 4, mean exposure doses of $\mathrm{As}, \mathrm{Cd}, \mathrm{Cr}, \mathrm{Cu}, \mathrm{Hg}, \mathrm{Ni}$, and $\mathrm{Pb}$ by meat consumption were $0.034,0.004,0.115,1.507,0.007,0.103$, and $0.055 \mu \mathrm{g} / \mathrm{kg}$ bw $/$ day. And high exposure values were $0.207,0.024,0.598,7.696,0.047,0.790$, and $0.339 \mu \mathrm{g} / \mathrm{kg}$ bw/day. Our mean exposure data (As, Cd, $\mathrm{Cr}, \mathrm{Hg}$ and $\mathrm{Pb}$ ) were lower than those reported in Beijing, China ${ }^{28}$.

To appraise the health risk associated with these metals, targeted hazard quotient (THQ) was calculated by dividing daily intake of elements by their reference doses. Hazard index (HI) combined all THQs was adopted to assess the total health risk ${ }^{39,40}$. An HI more than 1 is considered as not safe for human health. As shown in Table 5, all THQs were less than 1. Both mean and P97.5 HIs were no more than 1. HI for P97.5 level presented as the high exposure was 0.768 . It indicated that there was low health risk to exposure of common toxic elements by intake of these meats. However, it should be noticed that other potential exposure pathways for foods, such as vegetables, cereals, fruits, and fish might be considered except for livestock and poultry meats. 

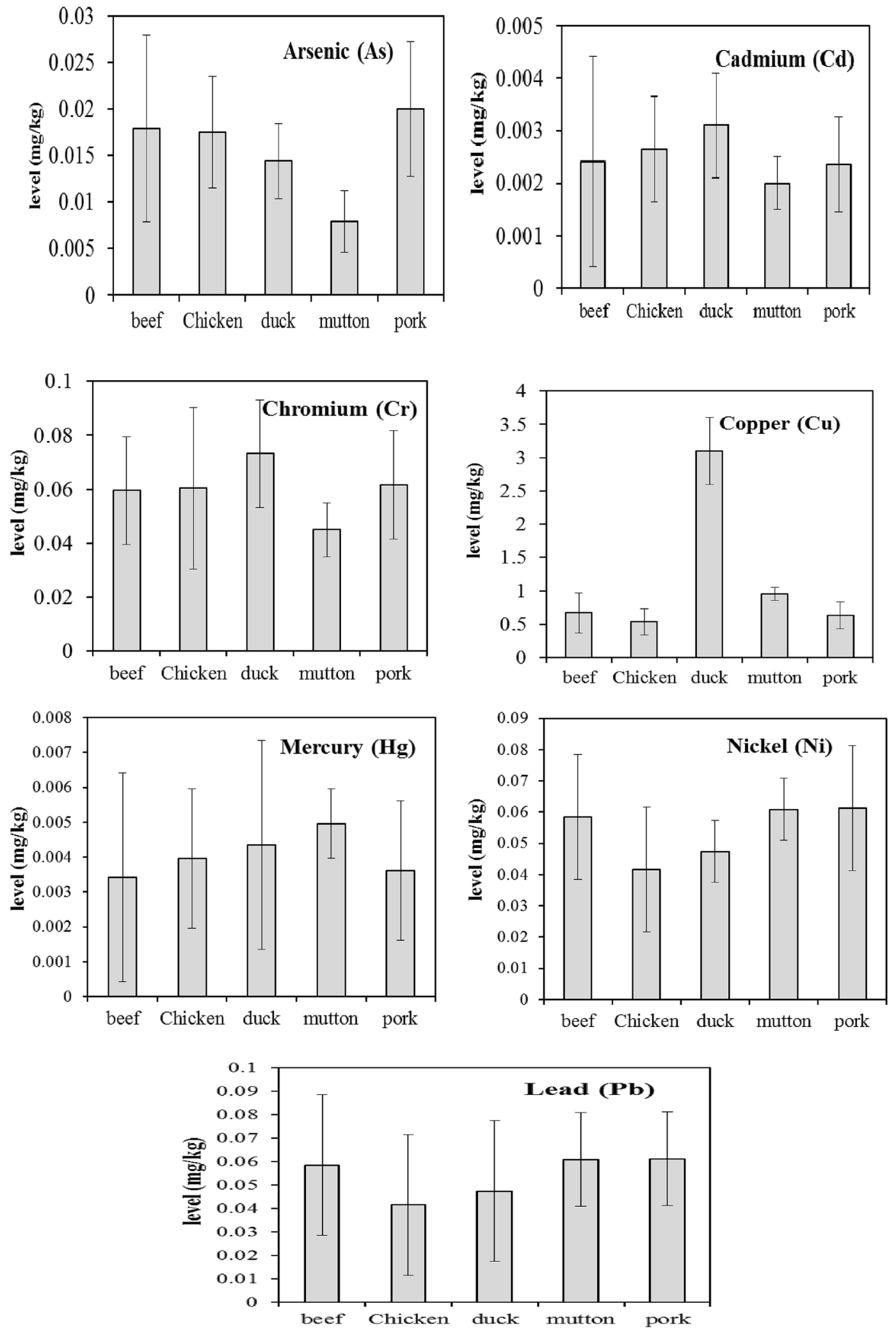

Figure 2. The levels of heavy metals ( $\mathrm{As}, \mathrm{Cd}, \mathrm{Cr}, \mathrm{Cu}, \mathrm{Hg}, \mathrm{Ni}$, and $\mathrm{Pb}$ in different meats. 


\begin{tabular}{|l|l|l|l|l|l|l|l|}
\hline & As & $\mathbf{C d}$ & $\mathbf{C r}$ & $\mathbf{C u}$ & $\mathbf{H g}$ & $\mathbf{N i}$ & $\mathbf{P b}$ \\
\hline $\mathrm{As}$ & 1 & & & & & & \\
\hline $\mathrm{Cd}$ & 0.1039 & 1 & & & & & \\
\hline $\mathrm{Cr}$ & 0.1096 & 0.5807 & 1 & & & & \\
\hline $\mathrm{Cu}$ & -0.0685 & $-\mathbf{0 . 6 5 1 5}$ & -0.3624 & 1 & & & \\
\hline $\mathrm{Hg}$ & 0.1041 & $\mathbf{0 . 9 1 4 1}$ & 0.5752 & -0.5708 & 1 & & \\
\hline $\mathrm{Ni}$ & 0.0672 & 0.5181 & 0.4162 & -0.2900 & 0.5052 & 1 & \\
\hline $\mathrm{Pb}$ & 0.0981 & $\mathbf{0 . 9 5 0 4}$ & 0.5695 & $-\mathbf{0 . 6 1 0 1}$ & $\mathbf{0 . 8 8 3 7}$ & 0.5010 & 1 \\
\hline
\end{tabular}

Table 4. Pearson correlations of the heavy metal pollutants in the meat samples. Significant values are in [bold].

\begin{tabular}{|c|c|c|c|c|c|c|c|}
\hline \multirow[b]{2}{*}{ Element } & \multirow[b]{2}{*}{ Safe value $(\mu \mathrm{g} / \mathrm{kg}$ bw/day) } & \multicolumn{2}{|c|}{$\begin{array}{l}\text { Exposure dose } \\
(\mu \mathrm{g} / \mathrm{kg} \text { bw/day })\end{array}$} & \multicolumn{2}{|c|}{$\begin{array}{l}\text { Targeted } \\
\text { hazard quotient } \\
\text { (THQ) }\end{array}$} & \multicolumn{2}{|c|}{$\begin{array}{l}\text { Hazard index } \\
\text { (HI) }\end{array}$} \\
\hline & & Mean & \begin{tabular}{|l|} 
P97.5 \\
\end{tabular} & Mean & P97.5 & Mean & P97.5 \\
\hline As & 3.0 & 0.034 & 0.207 & 0.011 & 0.069 & \multirow{7}{*}{0.146} & \multirow{7}{*}{0.896} \\
\hline $\mathrm{Cd}$ & 0.8 & 0.004 & 0.024 & 0.005 & 0.031 & & \\
\hline $\mathrm{Cr}$ & 3000 & 0.115 & 0.598 & 0.000 & 0.000 & & \\
\hline $\mathrm{Cu}$ & 40 & 1.507 & 7.696 & 0.038 & 0.192 & & \\
\hline $\mathrm{Hg}$ & 0.14 & 0.007 & 0.047 & 0.051 & 0.339 & & \\
\hline $\mathrm{Ni}$ & 20 & 0.103 & 0.790 & 0.005 & 0.040 & & \\
\hline $\mathrm{Pb}$ & 1.5 & 0.055 & 0.339 & 0.036 & 0.226 & & \\
\hline
\end{tabular}

Table 5. Estimated exposure to $\mathrm{As}, \mathrm{Cd}, \mathrm{Cr}, \mathrm{Cu}, \mathrm{Hg}, \mathrm{Ni}$, and $\mathrm{Pb}$ for the general population in livestock and poultry meats from Zhejiang province and the health risk assessment.

\section{Conclusion}

The present study revealed the levels of $\mathrm{As}, \mathrm{Cd}, \mathrm{Cr}, \mathrm{Cu}, \mathrm{Hg}, \mathrm{Ni}$, and $\mathrm{Pb}$ in livestock and poultry meats from Zhejiang of southeast China, which showed samples with $0.09 \%(\mathrm{As}), 0.19 \%(\mathrm{Hg})$ and $0.94 \%(\mathrm{~Pb})$ were exceeding the maximum allowable concentrations set by Chinese legislation. Obvious positive correlations among $\mathrm{Cd}, \mathrm{Hg}$ and $\mathrm{Pb}$ and negative correlations for $\mathrm{Cu}-\mathrm{Pb}$ and $\mathrm{Cu}-\mathrm{Cd}$ were found in analyzed samples. Dietary exposure assessment showed that there is relatively low health risk to these elements for general people in Zhejiang province of southeast China. However, it should be noted that the detailed information for animal species, feeding pattern cultivation, and feedstuffs was not involved in this study. Moreover, different heavy metal speciation showed diverse toxicity, such as organic and inorganic mercury. Our future survey will focus on the levels of heavy metal speciation in different animal products and feeds.

Received: 22 November 2021; Accepted: 14 February 2022

Published online: 25 February 2022

\section{References}

1. Bureau of Statistics. China Statistical Yearbook (China statistics press, 2016).

2. Soare, E. \& Chiurciu, I. A. Study on the pork market worldwide. Sci. Pap. Ser. Manage. Econ. Eng. Agric. Rural Dev. 17(4), 321-326 (2017).

3. He, Y., Yang, X., Xia, J., Zhao, L. \& Yang, Y. Consumption of meat and dairy products in China: a review. Proc. Nutr. Soc. 75, 385-391 (2016).

4. Yang, S. et al. Comparison of the concentrations, sources, and distributions of heavy metal (loid) s in agricultural soils of two provinces in the Yangtze River Delta, China. Environ. Pollut. 264, 114688 (2020).

5. Hu, B. et al. Current status, spatial features, health risks, and potential driving factors of soil heavy metal pollution in China at province level. Environ. Pollut. 266, 114961 (2020).

6. Chen, Q., Pan, X.-D., Huang, B.-F. \& Han, J.-L. Distribution of metals and metalloids in dried seaweeds and health risk to population in southeastern China. Sci. Rep. 8, 1-7 (2018).

7. Filippini, T. et al. Diet composition and serum levels of selenium species: a cross-sectional study. Food Chem. Toxicol. 115, 482-490 (2018).

8. Malavolti, M. et al. Lead exposure in an Italian population: Food content, dietary intake and risk assessment. Food Res. Int. 137, 109370 (2020).

9. Tao, C. et al. Heavy metal content in feedstuffs and feeds in Hubei Province China. J. Food Protect. 83, 762-766 (2020).

10. Wang, X. et al. Spatial analysis of heavy metals in meat products in China during 2015-2017. Food Control 104, 174-180 (2019).

11. Huang, Z., Pan, X.-D., Wu, P.-G., Han, J.-L. \& Chen, Q. Health risk assessment of heavy metals in rice to the population in Zhejiang China. PLoS ONE 8, e75007 (2013).

12. Wai, K. M. et al. Impact of prenatal heavy metal exposure on newborn leucocyte telomere length: a birth-cohort study. Environ. Pollut. 243, 1414-1421 (2018). 
13. Rehman, K., Fatima, F., Waheed, I. \& Akash, M. S. H. Prevalence of exposure of heavy metals and their impact on health consequences. J. Cell. Biochem. 119, 157-184 (2018).

14. Kim, J.-J., Kim, Y.-S. \& Kumar, V. Heavy metal toxicity: An update of chelating therapeutic strategies. J. Trace Elem. Med Biol. 54, 226-231 (2019).

15. Anyanwu, B. O., Ezejiofor, A. N., Igweze, Z. N. \& Orisakwe, O. E. Heavy metal mixture exposure and effects in developing nations: an update. Toxics 6, 65 (2018).

16. Aaseth, J., Hilt, B. \& Bjørklund, G. Mercury exposure and health impacts in dental personnel. Environ. Res. 164, 65-69 (2018).

17. Zhou, G., Zhang, W. \& Xu, X. China's meat industry revolution: challenges and opportunities for the future. Meat Sci. 92, 188-196 (2012).

18. Zhang, W. et al. Technological demands of meat processing-an Asian perspective. Meat Sci. 132, 35-44 (2017).

19. Pan, X. D., Tang, J., Chen, Q., Wu, P. G. \& Han, J. L. Evaluation of direct sampling method for trace elements analysis in Chinese rice wine by ICP-OES. Eur. Food Res. Technol. 236(3), 531-535 (2013).

20. Huang, Z., Pan, X.-D., Wu, P.-G., Han, J.-L. \& Chen, Q. Heavy metals in vegetables and the health risk to population in Zhejiang. China. Food Control 36, 248-252 (2014).

21. Han, J.-L., Pan, X.-D., Chen, Q. \& Huang, B.-F. Health risk assessment of heavy metals in marine fish to the population in Zhejiang, China. Sci. Rep. 11, 1-9 (2021).

22. GAQSIQ (General Administration of Quality Supervision, Inspection and Quarantine of the People's Republic of China) GB 5009.268-2016. National Food Safety Standard. Determination of Multi-elements in Food (in Chinese). Beijing: China Standards Press (2016).

23. ZJFDA. A report on the dietary intake in Zhejiang province, China. Hangzhou, ZJFDA. Available from: http://www.zjfda.gov.cn/ news/detail/13556.html (2008).

24. WHO. Reliable Evaluation of Low-Level Contaminants of Food. Workshop in the frame of GEMS/Food-EURO. Kulmbach, Germany. Available from: http://www.who.int/foodsafety/publications/chem/en/lowlevel_may1995.pdf (1995).

25. USEPA. Concepts, Methods, and Data Sources for Cumulative Health Risk Assessment of Multiple Chemicals, Exposures and Effects. A Resource Document. (US Environmental Protection Agency Washington, DC) (2007).

26. US EPA (United States Environmental Protection Agency). Region 9, Regional Screening Levels. Available on-line at. http://www. epa.gov/region9/superfund/prg/index.html (2010).

27. MHPRC (Ministry of Health of the People’s Republic of China) Maximum levels of contaminants in foods (GB2762-2017). Beijing, China: MHPRC. (In Chinese) (2017).

28. Liang, G. et al. Analysis of heavy metals in foodstuffs and an assessment of the health risks to the general public via consumption in Beijing, China. Int. J. Environ. Res. Public Health 16, 909 (2019).

29. Chen, S. S., Lin, Y. W., Kao, Y. M. \& Shih, Y. C. Trace elements and heavy metals in poultry and livestock meat in Taiwan. Food Addit. Contam. Part B 6(4), 231-236 (2013).

30. Abbas, M. et al. Public health risk of heavy metal residues in meat and edible organs of broiler in an intensive production system of a region in Pakistan. Environ. Sci. Pollut. Res. 26, 23002-23009 (2019).

31. Barone, G. et al. Trace metals in pork meat products marketed in Italy: occurrence and health risk characterization. Biol. Trace Elem. Res. 199(8), 2826-2836 (2020).

32. Aendo, P. et al. $\mathrm{Pb}, \mathrm{cd}$, and cu play a major role in health risk from contamination in duck meat and offal for food production in Thailand. Biol. Trace Elem. Res. 198(1), 243-252 (2020).

33. Hu, Y., Zhang, W., Chen, G., Cheng, H. \& Tao, S. Public health risk of trace metals in fresh chicken meat products on the food markets of a major production region in southern China. Environ. Pollut. 234, 667-676 (2018).

34. Kim, D.-G., Kim, M. K., Shin, J. Y. \& Son, S.-W. Cadmium and lead in animal tissue (muscle, liver and kidney), cow milk and dairy products in korea. Food Addit. Contam. Part B. Surveill. 9(1), 33-37 (2016).

35. Hashemi, M. Heavy metal concentrations in bovine tissues (muscle, liver and kidney) and their relationship with heavy metal contents in consumed feed. Ecotoxicol. Environ. Saf. 154, 263-267 (2018).

36. Cang, L., Wang, Y.-J., Zhou, D.-M. \& Dong, Y.-H. Heavy metals pollution in poultry and livestock feeds and manures under intensive farming in Jiangsu Province China. J. Environ. Sci. 16, 371-374 (2004).

37. Zhang, F., Li, Y., Yang, M. \& Li, W. Content of heavy metals in animal feeds and manures from farms of different scales in northeast China. Int. J. Environ. Res. Public Health 9, 2658-2668 (2012).

38. Attia, Y. et al. Effect of different dietary concentrations of inorganic and organic copper on growth performance and lipid metabolism of White Pekin male ducks. Br. Poult. Sci. 53, 77-88 (2012).

39. Chen, C. et al. Evaluation of pesticide residues in fruits and vegetables from Xiamen. China. Food Control 22, 1114-1120 (2011).

40. Osman, K. A., Al-Humaid, A., Al-Rehiayani, S. \& Al-Redhaiman, K. Estimated daily intake of pesticide residues exposure by vegetables grown in greenhouses in Al-Qassim region Saudi Arabia. Food Control 22, 947-953 (2011).

\section{Acknowledgements}

The authors would like to thank many colleagues in CDC of Zhejiang provincial cities for their laboratory work.

\section{Author contributions}

X.-D. P, and Q. C. conceived the experiment(s), X.-D. P, and Q. C.. conducted the experiment(s), X.-D. P, Q. C, and J.-L. H. analyzed the results. All authors reviewed the manuscript.

\section{Competing interests}

The authors declare no competing interests.

\section{Additional information}

Correspondence and requests for materials should be addressed to X.D.P.

Reprints and permissions information is available at www.nature.com/reprints.

Publisher's note Springer Nature remains neutral with regard to jurisdictional claims in published maps and institutional affiliations. 
(c) (i) Open Access This article is licensed under a Creative Commons Attribution 4.0 International cc) License, which permits use, sharing, adaptation, distribution and reproduction in any medium or format, as long as you give appropriate credit to the original author(s) and the source, provide a link to the Creative Commons licence, and indicate if changes were made. The images or other third party material in this article are included in the article's Creative Commons licence, unless indicated otherwise in a credit line to the material. If material is not included in the article's Creative Commons licence and your intended use is not permitted by statutory regulation or exceeds the permitted use, you will need to obtain permission directly from the copyright holder. To view a copy of this licence, visit http://creativecommons.org/licenses/by/4.0/.

(C) The Author(s) 2022 